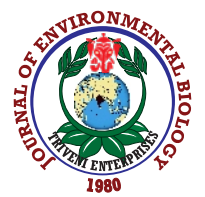

\title{
Changes in availability and uptake of soil phosphorus influenced by management practices and crop growth stages under peanut cultivation in medium black clay soil of Saurashtra region, Gujarat
}

\author{
R.S. Yadav ${ }^{1 *}$, H.N. Meena ${ }^{2}$, N.K. Jain ${ }^{3}$ and D. Bhaduri ${ }^{4}$ \\ ${ }^{1}$ ICAR - Central Arid Zone Research Institute (CAZRI), Jodhpur-342 003, India \\ ${ }^{2}$ ICAR-Agricultural Technology Application Research Institute, Jodhpur-342 003, India \\ ${ }^{3}$ HRM Unit, KAB-II, ICAR, New Delhi-110 012, India \\ ${ }^{4}$ ICAR-National Rice Research Institute (NRRI,CRRI), Cuttack-753 006 \\ *Corresponding Author Email : yadavrs2002@gmail.com
}

\section{Abstract}

Aim: To investigate efficient utilization of soil phosphorus for peanut nutrition through integration of management practices in medium black clay soils of Saurashtra region in Gujarat

Methodology: Soil phosphorus availability and uptake by peanut plants were assessed at five plant growth stages under six different management practices in Kharif season. The availability of soil $P$ was estimated by Olsen $\mathrm{P}$ and Resin P extraction methods. The biomass production and phosphorus uptake at each growth stages were observed in order to draw the relationship between these parameters.

Results: The management practices like raised bed with polythene mulch, integrated and organic nutrient management was consistently found promising for enhanced availability and uptake of soil phosphorus under peanut cultivation. The Olsen $\mathrm{P}$ decreased with plant growth under all the management options, except organic and integrated nutrient management practices. In contrary, the resin $\mathrm{P}$ generally increased with plant growth, especially under inorganic and organic nutrient management and raised bed with polythene mulch practices. Irrespective of growth stages, the phosphorus uptake by peanut plants was significantly and strongly correlated with biomass production $(r=0.85, p<0.01)$ and $O \operatorname{lsen} P(r=0.41, P<0.05)$.

Interpretation: The results indicate that phosphorus requirement of peanut plants can be efficiently met by integrating land and nutrient management practices in these medium black clay soils.

Key words: Black clay soil, Olsen P, Peanut, Phosphorus uptake, Resin $\mathrm{P}$

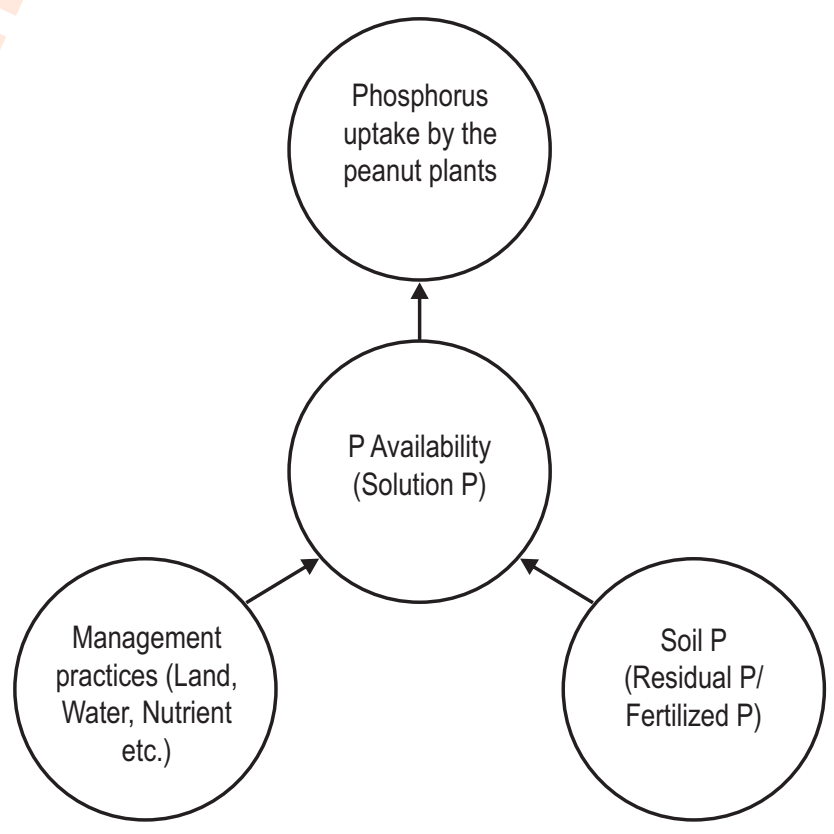

How to cite : Yadav, R.S., H.N. Meena, N.K. Jain and D. Bhaduri: Changes in availability and uptake of soil phosphorus influenced by management practices and crop growth stages under peanut cultivation in medium black clay soil of Saurashtra region, Gujarat. J. Environ. Biol., 41, 1781-1787 (2020). 


\section{Introduction}

In India, peanut is an important oilseed crop cultivated in about 6.77 million hectare area annually having quite low average productivity (about 1.5t ha ${ }^{-1}$ ) (Agricultural Statistics at a Glance, 2015). Low productivity is attributed mainly to the cultivation of crop on marginal lands having poor soil fertility in rain fed conditions (Sahrawat et al., 2010). More than 2/3rd of the total peanut cultivation area in India is confined to variable extent of calcareousness in the soils which is the major cause for imbalanced and poor nutrition of peanut plants in these soils. Being a legume, peanut has $\mathrm{N}$-fixation ability that adds nitrogen $\left(100-152 \mathrm{~kg} \mathrm{ha}^{-1} \mathrm{~N}\right)$ and organic matter to the soil (Nigam, 2015). Phosphorus is necessary for the development of legume nodule and associated nitrogen fixation (Parfitt et al., 2005) and, thus illustrating its agronomic importance in peanut production systems.

Phosphorus is an important element for plant growth, essentially required for energy transfer and nucleic acids (Marschner, 1995). It has a quite complex chemistry in the soil system having very low mobility and availability $(<3 \%)$ in most soils. Most of the phosphorus applied to agro-ecosystems is often immobilized in the soil through sorption and precipitation with other cations (Garg and Bahl, 2008). Immobilized phosphorus exists in a multitude of chemical forms and pools that become available to plants on different time scales. In normal conditions, phosphorus exists in soil in two forms: inorganic $\mathrm{P}(\mathrm{Pi})$ and organic $P(P o)$. Despite of sufficient total $P$ exists in soil systems, only a small fraction may be available to plants and microbes either as $\mathrm{HPO}_{4}{ }^{2-}$ and/or $\mathrm{H}_{2} \mathrm{PO}_{4}$ ions in soil solution (Richardson, 2001). Soil $P$ dynamics is governed by physico-chemical (sorption-desorption) and biological (immobilizationmineralization) processes. The dynamics of phosphorus in calcareous soil environments is largely controlled by two major mineral components viz., iron oxides and calcium carbonates (Matar et al., 1992). The P- fertilizer applied in these soils gets converted into immobile pools through precipitation reaction with $\mathrm{Ca}^{2+}$ cation (Gyaneshwar et al. 2002). Therefore, the availability as well as efficiency of applied $P$-fertilizer is very low in these soils.

Plants and microbes have evolved with some mechanisms to obtain soil phosphorus with biological transformations of phosphorus compounds present in the soils which are fundamental for phosphorus cycling (Richardson et al., 2011; Bünemann, 2015). The conceptual model of Shen et al. (2011) depicted a great scope for root/rhizosphere and soil-based nutrient managements for improving P-use efficiency and crop productivity in intensive agriculture. P-uptake of peanut plants was also found to cultivar-specific under similar experimental conditions since cultivars TG 37A and GG 7 accumulated more leaf- $P$ and root- $P$ under long-term salinity trial, when salinity played a crucial role in determining P-uptake (Bhaduri et al., 2016). Poor soil-P availability, high fixation, inconsistent and variable response of applied phosphorus fertilizers with poor use efficiency (Syers et. al. 2008) and indefinite role of residual soil phosphorus are some of the major issues regarding phosphorus nutrition in plants. Therefore, the present study aimed to enhance availability and uptake of soil phosphorus through management interventions in peanut production in medium black clay soils of Saurashtra region in Gujarat.

\section{Materials and Methods}

Experimental site characteristics : The experiment was conducted at research farm of ICAR-Directorate of Groundnut Research, Junagadh, India. The experimental site is located in the foothills of Mt. Girnar in the southern region of Saurashtra $\left(70.36^{\circ} \mathrm{E}\right.$ longitude and $21.31^{\circ} \mathrm{N}$ latitude; $60 \mathrm{~m}$ above mean sea level). The climate of this area is semi-arid with an average rainfall of $650 \mathrm{~mm}$. The soil of the experimental site was Typic Haplustepts (USDA soil classification), medium black clay (52$55 \%$ ) having variable degree of calcareousness and developed on weathered hard milliolithic limestone parent materials of basaltic rocks. Soils was alkaline nature ( $\mathrm{pH} 7.45$ - 8.15), low in available nitrogen and phosphorus and medium in available potassium. The cation exchange capacity (CEC) ranged from 40$62 \mathrm{cmol}^{(+)} \mathrm{kg}^{-1}$ soil, dominated by $\mathrm{Ca}^{+2}(60-75 \%)$ and $\mathrm{Mg}^{+2}(15-$ $20 \%$ ) cations. Soil organic carbon ranged from 5.21 to $8.75 \mathrm{~g} \mathrm{~kg}^{-1}$ in the root zone. Water retention capacity of soil was about 24$30 \%$ at field capacity $\left(1 / 3^{\text {rd }}\right.$ bar) and $14-16 \%$ at wilting point (15 bar).

Experimental and sampling details : Soil and plant samples were collected from experiments conducted on a fixed site for last three years for fertilizer management and land configuration during kharif season. The experimental details including land, nutrients and water management practices using peanut cultivars are given in Table 1. The experimental plots were prepared using deep tillage during $2^{\text {nd }}$ fortnight of June. Conventional sowing of peanut 'TG 37A and GG 20' was carried out using $100 \mathrm{~kg}$ kernels $\mathrm{ha}^{-1}$ in the last week of June to second week of July at $30 \mathrm{~cm} \times 10$ $\mathrm{cm}$ spacing in flats beds and $20 \mathrm{~cm} \times 20 \mathrm{~cm}$ in raised beds with or without polythene mulch. Fertilizers (N, P, and $\mathrm{K}$ ) as specified were applied in the form of urea, single super phosphate and muriate of potash, respectively, at the time of sowing. The preemergence herbicide, pendimethalin was applied @ $1.0 \mathrm{~kg} \mathrm{ha}^{-1}$ in $700 \mathrm{~L}$ of water and the plots were maintained weed free by hand weeding during growing period.

Soil and plant analysis : The soil and plant samples were collected at vegetative, flowering, pegging, pod filling and maturity stages. Soil samples were drawn from $0-20 \mathrm{~cm}$ soil depth at field capacity and immediately analysed for Olsen P (Olsen et. al., 1954) on dry weight basis. For resin $P$, bicarbonate charged resin bags were buried in the peanut rhizosphere (0-20 cm depth) at field capacity. The resin adsorbed $P$ was eluted in $1 \mathrm{M}$ hydrochloric acid after 48 hrs and estimated as described by 
Table 1 : Experimental details including tillage, inputs and irrigation used under nutrient and land management practice for peanut cultivation. Three replications were used for each treatment.

\begin{tabular}{|c|c|c|c|c|}
\hline Treatments & Tillage & Organics & $\begin{array}{l}\text { Fertilizers } \\
\left(\mathrm{NPK}^{*}\right)\end{array}$ & Irrigation \\
\hline \multicolumn{5}{|c|}{ Nutrient Management } \\
\hline Inorganic & Deep ploughing followed by harrowing and planking & - & $25-50-30$ & Surface method \\
\hline Organic & Deep ploughing followed by harrowing and planking & FYM@10tha-1 & - & Surface method \\
\hline Integrated & Deep ploughing followed by harrowing and planking & $\begin{array}{l}\text { FYM @ 5 tha-1+ } \\
500 \text { kg Gypsum }\end{array}$ & $12.5-25-00$ & Surface method \\
\hline \multicolumn{5}{|l|}{ Land Management } \\
\hline Conventional & Deep ploughing followed by harrowing and planking & - & $25-50-30$ & Surface method \\
\hline Raised Bed & $\begin{array}{l}\text { Deep ploughing followed by harrowing and planking } \\
\text { and making raised beds }\end{array}$ & - & $25-50-30$ & Surface method \\
\hline Raised bed with PM & $\begin{array}{l}\text { Deep ploughing followed by harrowing and planking } \\
\text { and making raised beds and spreading PM }\end{array}$ & - & $25-50-30$ & Surface method \\
\hline
\end{tabular}

${ }^{*} \mathrm{NPK} ; \mathrm{N}: \mathrm{P}_{2} \mathrm{O}_{5}: \mathrm{K}_{2} \mathrm{O}$ in kg ha ${ }^{-1}$, PM; Polythene mulch of $7 \mu$ thickness, FYM; Farm yard manure, PM; Polythene mulch

Sibbesen (1978). The other soil properties were analysed using standard methodology as described by Jackson (1967). The plant samples were also collected at each growth stages and observed fresh as well as oven dry weight. The dried plant samples were ground in the ball mill and digested using tri-acid mixture $\left(\mathrm{HNO}_{3}\right.$ : $\left.\mathrm{H}_{2} \mathrm{SO}_{4}: \mathrm{HClO}_{4}\right)$ (Jackson, 1967). The plant $\mathrm{P}$ was estimated colorimetrically as described by Kitson and Mellon (1944).The results were statistically analysed for least significant difference by ANOVAusing SAS software.

\section{Results and Discussion}

The availability of soil $P$ was observed using Olsen $P$ and Resin P estimations at five critical stages of plant growth viz., vegetative, flowering, pegging, pod filling and maturity in peanut production. A wide variation was observed in average values for Olsen P (9.13 mg kg to $\left.30.51 \mathrm{mg} \mathrm{kg}^{-1}\right)$ and Resin P $\left(5.77 \mathrm{mg} \mathrm{kg}^{-1}\right.$ to $15.30 \mathrm{mg} \mathrm{kg}^{-1}$ ) among different management practices (Table 2). Management practices like raised bed with polythene mulch (RB-PM), integrated nutrient management (INM) and organic nutrient management were found most congenial for enhanced availability of soil $P$ both as Olsen $P(30.51,25.36$ and $13.73 \mathrm{mg}$ $\left.\mathrm{kg}^{-1}\right)$ and $\operatorname{Resin} P\left(15.30,13.34\right.$ and $\left.14.19 \mathrm{mg} \mathrm{kg}^{-1}\right)$. The availability of both Olsen $\mathrm{P}$ and Resin $\mathrm{P}$ were poorly recovered under inorganic nutrient management ( 18.55 and $6.70 \mathrm{mg} \mathrm{kg}^{-1}$ ), raised bed (13.17 and $5.77 \mathrm{mg} \mathrm{kg}^{-1}$ ) and conventional land (9.13 and $6.24 \mathrm{mg} \mathrm{kg}^{-1}$ ) management practices, respectively.

A significant change was observed in the availability of soil phosphorus both Olsen $\mathrm{P}$ and Resin $\mathrm{P}$ among different plant growth stages of peanut. In general, higher Olsen $P$ was observed at vegetative growth stage, except organic and INM practices in which Olsen $\mathrm{P}$ increased with plant growth up to pod filling stage (Fig. 1). It is clearly evident that Olsen P, generally considered as an indicator for soil $P$ availability significantly decreased with plant growth under inorganic nutrient and conventional land management practices and sustained up to pod filling and maturity growth stages with organic and INM with raised bed with/without polythene mulch. In contrary, Resin P availability increased consistently with plant growth up to pegging and/or pod filling stages under inorganic, organic and raised bed with PM management practices. However, INM, conventional and raised bed management practices showed almost consistent availability of Resin P throughout plant growth stages.

The overall $\mathrm{P}$ dynamics in the soil plant system is a function of integrative effects of $P$ transformation, availability and utilization caused by soil, rhizosphere and plant processes (Shen et al., 2011). The root induced changes, including proton release (Bertrand et al. 1999), carboxylate exudation (Jones, 1998) and secretion of phosphatases enzymes to mobilize organic phosphorus (Tarafdar et al., 2001) are key mechanisms to obtain soil phosphorus with biological transformations of phosphorus compounds present in the soils, which are fundamental for phosphorus cycling (Richardson et al., 2011, Bünemann, 2015). The enhanced availability of soil phosphorus in raised bed with polythene mulch, INM and organic nutrient management practices might be due to better microbial and root activities in the rhizosphere of peanut at different crop growth stages. In calcareous soils, the dynamics of phosphorus is controlled by calcite and iron oxides such as goethite which strongly retain phosphorus and consequently maintain low $\mathrm{P}$ concentrations in soil solution. In these soils, phosphorus retention is dominated by precipitation reactions (Devau et al., 2010) which are less available to plants at alkaline pH (Arai and Sparks, 2007). Phosphorus transformations in these soils also reduced soil organic carbon and carbon to organic phosphorus ratio likely by promoting organic acid exudation and secretion of enzymes by roots and soil microbiota (Romanya et al., 2017). About $90 \%$ of variations in Olsen-P could be explained by Pi fractions, and direct contribution of $\mathrm{Ca}^{8}-\mathrm{P}$ was predominant. Long-term annual superphosphate application would facilitate accumulation of soil 
Table 2 : Effect of different management practices on phosphorus availability and uptake by the groundnut; \pm represents values for standard error of mean, The diffrent post-scripts represents significant values $(p=0.05)$.

\begin{tabular}{lllll}
\hline Management practices & Olsen's $\mathbf{P}\left(\mathbf{m g ~ k g}^{-1}\right)$ & Resin $\mathbf{P}\left(\mathrm{mg} \mathrm{kg}^{-1}\right)$ & Biomass $(\mathbf{g}$ plant $)$ & P uptake $\left(\mathrm{mg} \mathrm{plant}^{-1}\right)$ \\
\hline $\begin{array}{l}\text { Nutrient Management } \\
\text { Inorganic }\end{array}$ & $18.55 \pm 1.45 \mathrm{c}$ & $6.70 \pm 0.41 \mathrm{a}$ & & \\
Organic & $13.73 \pm 1.05 \mathrm{~b}$ & $14.19 \pm 1.17 \mathrm{~b}$ & $16.45 \pm 1.08 \mathrm{c}$ & $34.10 \pm 2.39 \mathrm{~d}$ \\
Integrated & $25.36 \pm 2.08 \mathrm{~d}$ & $13.34 \pm 1.11 \mathrm{~b}$ & $12.40 \pm 0.98 \mathrm{~b}$ & $22.91 \pm 1.61 \mathrm{ab}$ \\
Land Management & & & & $26.59 \pm 2.27 \mathrm{c}$ \\
Conventional & $9.13 \pm 0.81 \mathrm{a}$ & $6.24 \pm 0.36 \mathrm{a}$ & $10.19 \pm 0.72 \mathrm{a}$ & $22.37 \pm 1.61 \mathrm{ab}$ \\
Raized bed & $13.17 \pm 1.02 \mathrm{~b}$ & $5.77 \pm 0.47 \mathrm{a}$ & $8.83 \pm 0.56 \mathrm{a}$ & $19.25 \pm 1.27 \mathrm{a}$ \\
Raised bed with PM & $30.51 \pm 2.36 \mathrm{e}$ & $15.30 \pm 1.14 \mathrm{~b}$ & $13.74 \pm 1.06 \mathrm{~b}$ & $32.06 \pm 2.55 \mathrm{~d}$ \\
\hline
\end{tabular}

Table 3 : Correlation matrix of different soil and plant parameters $\left({ }^{*} \mathrm{p}=0.05\right.$ and $\left.{ }^{* *} \mathrm{p}=0.01\right)$

\begin{tabular}{llllll}
\hline & Olsen $P(0)$ & Resin $P(R)$ & $0+R$ & Biomass & P-uptake \\
\hline Olsen P(O) & 1.00 & $0.45^{*}$ & $0.93^{* *}$ & 0.17 & $0.41^{*}$ \\
Resin P(R) & & 1.00 & $0.74^{*}$ & 0.30 & 0.18 \\
O+R & & 1.00 & 0.25 & $0.38^{*}$ \\
Biomass & & & 1.00 & $0.85^{* *}$ \\
P-uptake & & & & 1.00 \\
\hline
\end{tabular}

$\mathrm{Ca}{ }^{8}-\mathrm{P}$, thus improving soil phosphorus availability (Wang et al., 2010). Addition of manures or lime, and adoption of no-till agriculture can lead to increase in organic $\mathrm{P}$ forms, and/or a higher proportion of calcium-stabilized $\mathrm{P}$ as soil $\mathrm{pH}$ rises (Rodrigues et al., 2015).

A significantly higher biomass production was observed with inorganic nutrient management (16.45 $\left.\mathrm{g} \mathrm{plant}^{-1}\right)$ followed by raised bed with PM (13.74 $\left.\mathrm{g} \mathrm{plant}^{-1}\right)$ then INM (12.50 $\left.\mathrm{g} \mathrm{plant}^{-1}\right)$, organic nutrient management (12.40 $\left.\mathrm{g} \mathrm{plant}^{-1}\right)$, conventional land management $\left(10.99 \mathrm{~g} \mathrm{plant}^{-1}\right)$ and least in raised bed $(8.83 \mathrm{~g}$ plant $\left.{ }^{1}\right)$ among the management practices (Table 2). Almost similar trend was observed at different plant growth stages for these management practices. A continuous increase in peanut biomass production was observed with plant growth up to pod filling stage under all the management practices (Fig. 2). This increase was significantly higher for inorganic nutrient management. Similarly, a significant $(p=0.05)$ difference was observed in plant $P$-uptake with highest under inorganic nutrient management $(34.10 \mathrm{mg}$ plant $^{-1}$ ) which was at par to raised bed with PM (32.06 mg plant $^{-1}$ ) land management, significantly higher than rest treatments both under nutrient and land management practices (Table 2). The effect of plant growth on phosphorus-uptake was also found highest under inorganic nutrients followed by raised bed with PM management practices at vegetative and flowering stages and at par with pegging stage. However, the highest phosphorus-uptake was observed under raised bed with PM management practice at pod-filling and maturity stages followed by INM practice.

Various soil and plant properties can affect the biomass production and nutrient acquisition by the plants. Soil $\mathrm{pH}$, soil organic matter, soil biological activity, soil moisture, plant root system, rhizo-depositions, root induced chemical changes etc. are important limiting factors for availability and uptake of soil phosphorus by the plants (Neumann and Roemheld, 2002). Localized application of phosphates plus ammonium significantly enhances phosphorus uptake and crop growth through stimulating root proliferation and rhizosphere acidification in calcareous soil (Jing et al., 2010). Management practices like inorganic nutrient management, raised bed with polythene mulch, INM and organic nutrient management practices appreciably increased the biomass production as well as phosphorus-uptake by peanut plants (Table 2). Polythene drip and resource conservation management practices were found promising for creating congenial conditions to solubilize and mobilize soil phosphorus in to different conceptual pools in the soil (Yadav et al. 2017). Polythene mulch helps to maintain optimum soil moisture, aids seed establishment, and promotes excellent crop growth throughout the season (Jain et al., 2017). For example, Olsen P was appreciably larger for soil with more soil organic matter in an experiment with a sandy loam soil (Johnston, 2001).The most plausible form of $P$ supplied to plants is from Olsen-P and Pi pools and through mineralization of Po (Aulakh et al., 2003). Besides, this polythene film mulch also provides mechanical protection at soil surface and favourable microclimate in terms of soil temperature, soil moisture and $\mathrm{CO}_{2}$ supply to the stomata for enhanced assimilation of photosynthetes (Singh et al., 2004, Nalayini et al., 2009). The beneficial effects of polythene mulch are also for enhanced utilization of water and fertilizer and weed (Mahajan et al., 2007; Nalayini et al., 2009) and pests control (Ramakrishna et al., 2006). Overall the polythene drip and resource conservation management practices were found promising for creating congenial conditions to solubilize and 

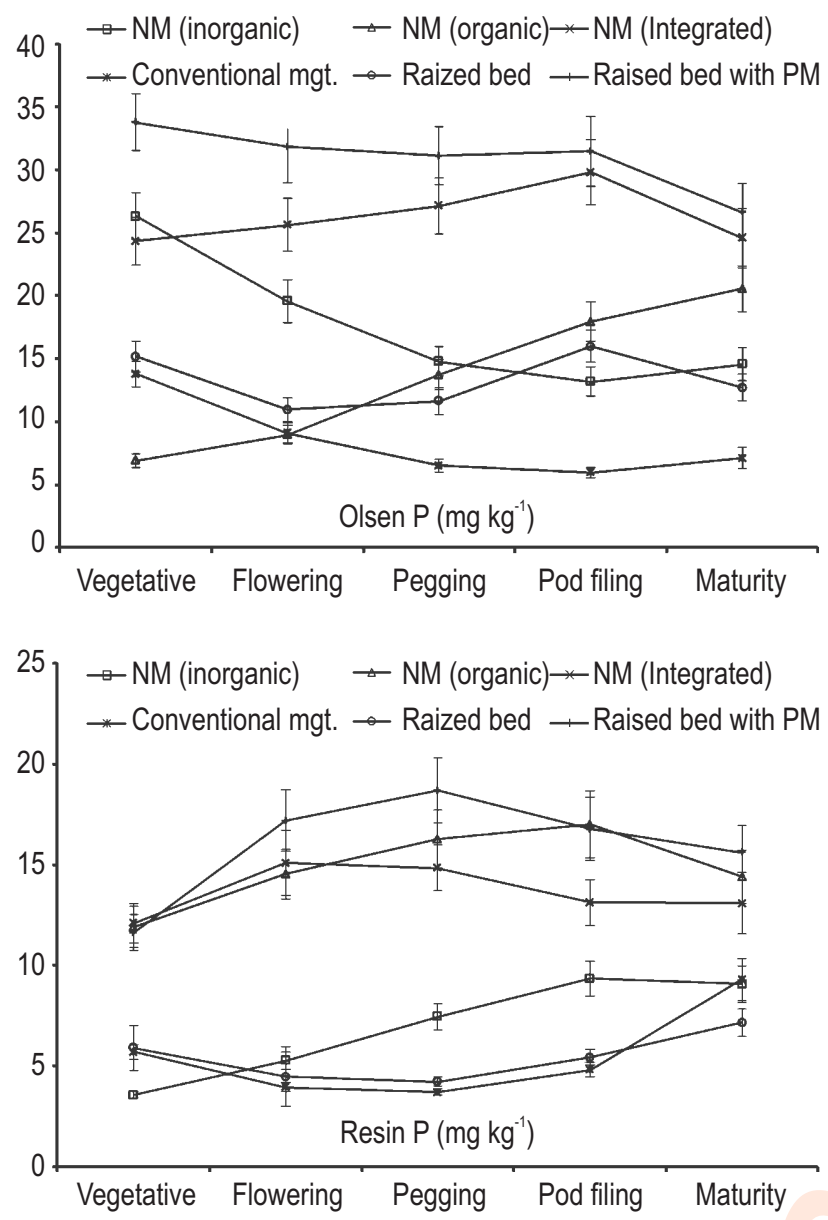

Fig. 1 : Changes in soil available phosphorus with plant growth under different management practices. \pm represents values for standard error of mean, NM; Nutrient management.

mobilize the soil phosphorus in to different conceptual pools in the soil (Yadav et al. 2017). Agro-engineering including innovative and integrated soil, crop and nutrient management, including manures and recovered phosphorus substantially managed the availability and acquisition of legacy soil phosphorus and help to offset the yield dips in agricultural production systems (Rowe et al. 2016).

A significant relationship was observed between phosphorus availability (Olsen $\mathrm{P}$, Resin $\mathrm{P}$ and Olsen + Resin $\mathrm{P}$ ) as well as P-uptake by peanut plants (Table 3 ). The Olsen $P$ is significantly correlated well with Resin P $(r=0.45)$ and Olsen $P+$ $\operatorname{Resin} P(r=0.93)$. Similarly, Resin $P$ was correlated with Olsen $P+$ Resin $P(r=0.74)$. The phosphorus-uptake by plants is strongly correlated with peanut biomass production $(r=0.85)$ and also significantly correlated with Olsen $\mathrm{P}(\mathrm{r}=0.41)$ and Olsen $\mathrm{P}+\mathrm{Resin}$ $P(r=0.38)$. However, the availability of soil phosphorus was poorly correlated with peanut biomass production. Though, these relationships may be altered with specific plant growth stages.
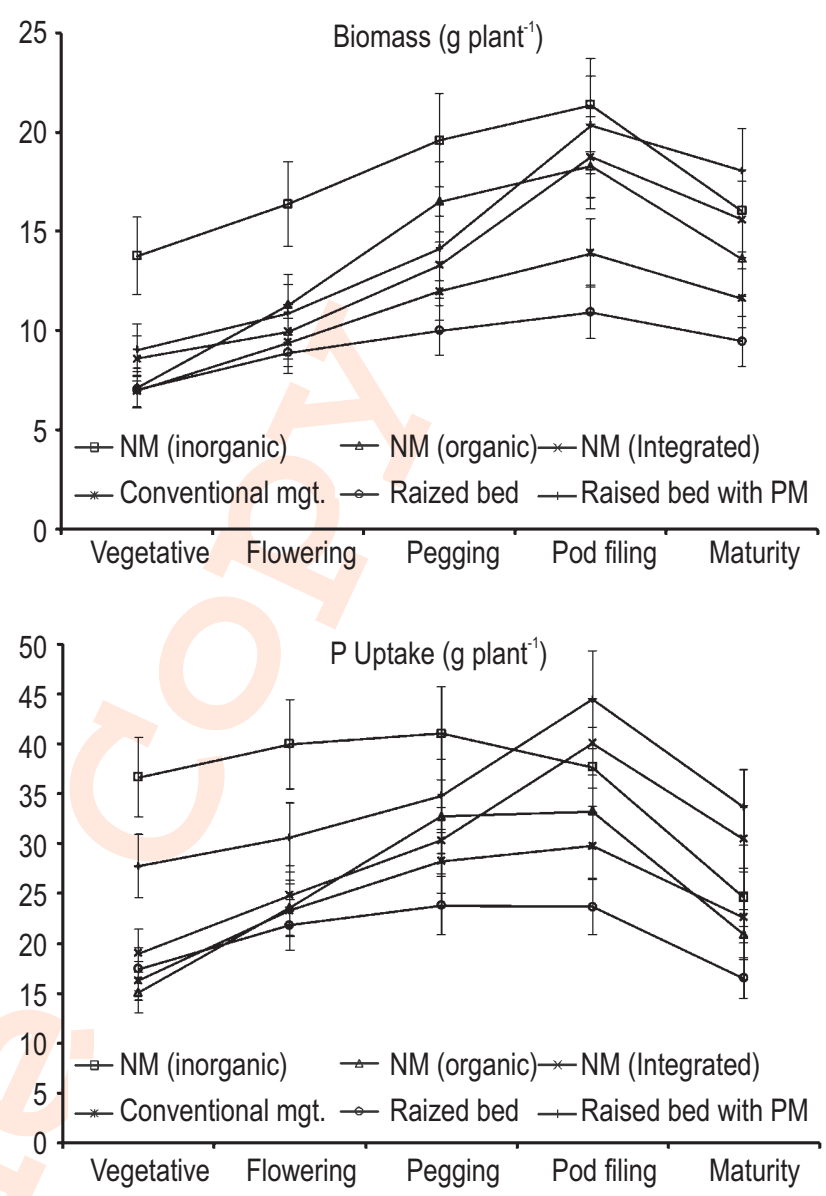

Fig. 2 : Changes in biomass production and $P$ uptake in peanut with plant growth under different management practices. \pm represents values for standard error of mean, NM; Nutrient management.

The amount of phosphorus uptake by plants was strongly dependent on the amount of labile-Pi in the soil. This result is in agreement with the studies of Linquist et al. (1997) and Guo et al. (2000). Further, Linquist et al. (1997) found that in zero applied phosphorus treatment, $\mathrm{NaHCO}_{3}$-Po was correlated with labile-Pi, soybean dry matter, yield and phosphorus uptake, suggesting that mineralized Po is an important source of plant phosphorus in unfertilized systems. This result is supported by the studies of Beck and Sanchez (1994) and suggested that in unfertilized cropping systems, Po mineralization may be a major source of plant phosphorus. Henríquez and Killorn (2005) reported that the amount of plant $P$ uptake was closely related to the initial amount of labile-Pi. Rapid changes in reversibly available soil $P$ forms ( $\mathrm{NaOH}-\mathrm{Pi}$ and $\mathrm{HCl}-\mathrm{Pi}$ ) were observed during the experiment. The combined use of organic and inorganic fertilizers in low input systems may promote increased biological cycling, enhanced availability and consequently improved plant uptake of soil and fertilizer phosphorus (Ayaga et al., 2006). The integrated use of low-P organic manures with mineral nitrogen and potassium 
considerably activate the plant available phosphorus pool for plant nutrition (Shi et al., 2015). A strong relationship was observed among the labile phosphorus fraction with Olsen $\mathrm{P}$ and total $P$, whereas residual $P$ was negatively correlated with dilute $\mathrm{HCl}$ extractable Pi fraction (Ahmed et al., 2019). Further, application of NPKM (NPK + Manure) improved phosphorus availability many fold than application of NPK only (Ahmed et al. 2019). Our results suggest the occurrence of rapid and dynamic changes occurred between available and unavailable soil phosphorus forms in response to fertilizer application and plant uptake, supporting the idea of a continuum among the phosphorus forms.

This study showed a future roadmap to peanut growers for opting suitable management practices in terms of better $P$ nutrition, with a special reference to medium black clay soils, prominent in western part of India.

\section{Acknowledgment}

The authors gratefully acknowledge the Director, ICARDirectorate of Groundnut Research, Junagadh for providing all facilities to conduct these experiments.

\section{References}

Agriculture Statistics at a Glance: Government of India, Ministry of Agriculture and Farmers Welfare, Department of Agriculture, Cooperation and Farmers Welfare, Directorate of Economics and Statistics (2015)

Ahmed, W., H. Jing, L. Kaillou, M. Qaswar, M.N. Khan, C. Jin, S. Geng, H. Qinghai, L. Yiren, L. Guangrong, S. Mei, L. Chao, L. Dongchu, S. Ali, Y. Normatov, S. Mehmood and H. Zhang: Changes in phosphorus fractions associated with soil chemical properties under long-term organic and inorganic fertilization in paddy soils of southern China. PLoS ONE, 14, e0216881 (2019).

Arai, Y. and D.L. Sparks: Phosphate reaction dynamics in soils and soil minerals: A multi-scale approach. Adv. Agron., 94, 135-179 (2007).

Aulakh, M. S., B.S. Kabba, H. Baddesha, G.S. Bahl and M. Gill: Crop yields and phosphorus fertilizer transformations after 25 years of applications to a subtropical soil under groundnut-based cropping systems. Field Crop Res., 83, 283-296 (2003).

Ayaga, G., A. Todd and P.C. Brookes: Enhanced biological cycling of phosphorus increases its availability to crop in low-input subSaharan farming system. Soil Biol. Biochem., 38, 81-90 (2006).

Beck, M.A. and P.A. Sanchez: Soil phosphorus fraction dynamics during 18 years of cultivation on a TypicPaleoudult. Soil Sci. Soc. Am. J. 58, 1424-1431 (1994).

Bertrand, I., Hinsinger P, Jaillard B. and J.C. Arvieu: Dynamics of phosphorus in the rhizosphere of maize and rape grown on synthetic, phosphated calcite and goethite. Plant and Soil, 211, 111-119(1999).

Bhaduri, D., H.N. Meena and K. Chakraborty: Variation in phosphorus accumulation in groundnut cultivars as influenced by water salinity. Leg. Res., 39, 215-220 (2016).

Bünemann, E.K.: Assessment of gross and net mineralization rates of soil organic phosphorus: A review. Soil Biol. Biochem., 89, 82-98 (2015).

Devau, N., E. Le Cadre, P. Hinsinger and F. Gerard: A mechanistic model for understanding root-induced chemical changes controlling phosphorus availability. Ann. Bot. (Lond), 105, 1183-1197 (2010).

Henríquez, C. and R. Killorn: Soil P forms and P uptake under intensive plant growth in the greenhouse. Agron. Costa., 29, 83-97 (2005).

Garg, S. and G. Bahl: Phosphorus availability to maize as influenced by organic manures and fertilizer $P$ associated phosphatase activity in soils. Biores. Technol., 99, 5773-5777 (2008).

Guo, F., R.S. Yost, N.V. Hue, C.I. Evenson and J.A. Silva: Changes in phosphorus fractions in soils under intensive plant growth. Soil Sci. Soc. Am. J., 64, 1681-1689 (2000).

Gyaneshwar, P., K.G. Naresh, L.J. Parekh and P.S. Poole: Role of soil micro-organisms in improving P nutrition of plants. PI. Soil, 245, 83-93 (2002).

Jackson, M.L.: Soil Chemical Analysis. Prentice-Hall of India, Delhi, p. 498 (1967).

Jain, N.K., H.N. Meenaand and D. Bhaduri: Improvement in productivity, water-use efficiency, and soil nutrient dynamics of summer peanut (Arachis hypogaea L.) through use of polythene mulch, hydrogel, and nutrient management. Comm. Soil Sci. Pl. Anal., 48, 549-564 (2017).

Jing, J.Y., Y.K. Rui, F.S., Zhang, Z. Rengel and J.B. Shen: Localized application of phosphorus and ammonium improves growth of maize seedlings by stimulating root proliferation and rhizosphere acidiûcation. Field Crops Res., 119, 355-364 (2010).

Johnston, A.E.: Principles of crop nutrition for sustainable food production. Proceedings of the International Fertilizer Society 459, York, UK, p.39 (2001).

Jones, D.L.: Organic acids in the rhizosphere- a critical review. Plant Soil, 205, 25-44 (1998).

Kitson, R. and M. Mellon: Colorimetric determination of phosphorus as molybdivanadophosphoric acid. Indust. Engin. Chem. Analy., Edition 16, 379-383 (1944).

Linquist, B.A., P.W. Singleton and K.G. Cassman: Inorganic and organic phosphorus dynamics during a build-up and decline of available phosphorus in an Ultisol. Soil Sci., 162, 254-264 (1997).

Mahajan, G., R. Sharda, A. Kumar and K.G. Singh: Effect of plastic mulch on economizing irrigation water and weed control in baby corn sown by different methods. African J. Agric. Res., 2,19-26 (2007).

Marschner, $H .:$ Mineral nutrition of higher plants. $2^{\text {nd }}$ Edn., Academic Press, London, UK, pp. 889 (1995).

Matar, A., J. Torrent and J. Ryan: Soil and fertilizer phosphorus and crop responses in the dryland Mediterranean zone. Adv. Soil Sci., 18, 81-146 (1992).

Nalayini, P., R. Anandham, K. Sankaranarayanan and T.P. Rajendran: Polyethylene mulching for enhancing crop productivity and water use efficiency in cotton (Gossypium hirsutum) and maize (Zea mays) cropping system. Indian J. Agro., 54,409-414 (2009).

Nigam, S.N.: Groundnut at a glance. Open access repository ICRISAT, Patancheru, Hyderabad, Telangana, pp. 121 (2014). http://oar.icrisat.org/8455/1/Groundnut\%20at\%20a\%20Glance.

Neumann, G. and V. Roemheld: Root-induced changes in the availability of nutrients in the rhizosphere. In: Plant Roots-The Hidden Half (Eds.: Y. Waisel, A. Eshel and U. Kafkaû). $3^{\text {rd }}$ Edn., Marcel Dekkerlnc., New York, pp. 617-649 (2002).

Olsen, S.R., C.V. Cole, F.S. Watanabe and L.A. Dean: Estimation of available phosphorus in soils by extraction with sodium bicarbonate. USDA Circ. 939 (1954). 
Parfitt, R.L., G.W. Yeates, D.J. Ross, A.D. Mackay and P.J. Budding: Relationships between soil biota, nitrogen and phosphorus availability, and pasture growth under organic and conventional management. Appl. Soil Ecol., 28, 1-13 (2005).

Ramakrishna, A., H.M. Tam, S.P. Wani and T.D. Long: Effect of mulch on soil temperature, moisture, weed infestation and yield of groundnut in northern Vietnam. Field Crops Res., 95, 115-125 (2006).

Richardson, A.E.: Prospects for using soil micro-organisms to improve the acquisition of phosphorus by plants. Australian. J. PI. Physiol. 28, 897-906 (2001).

Richardson, A.E., J.P. Lynch, P.R. Ryan, E. Delhaize, F.A. Smith, S.E. Smith, P.R. Harvey, M.H. Ryan, E.J. Veneklaas, H. Lambers, A. Oberson, R.A. Culvenor and R.J. Simpson: Plant and microbial strategies to improve the phosphorus efficiency of agriculture. Plant and Soil, 349, 121-56 (2011).

Rodrigues, M., P.S. Pavinato, P.J.A. Withers, A.P. Bettoni Teles and W.F.B. Herrera: Legacy phosphorus and no tillage agriculture in tropical Oxisols of the Brazilian savanna. Sci. Total Environ., 542, 1050-61 (2015).

Romanya, J., J.M. Blanco-moreno and F.X. Sans: Phosphorus mobilization in low-P arable soils may involve soil organic carbon depletion. Soil Biol. Biochem., 113, 250-259 (2017).

Rowe, H., P.J.A. Withers, P. Baas, N.I. Chan, D. Doody, J. Holiman, B. Jacobs, H. Li, G.K. MacDonald, R. McDowell, A.N. Sharple, J. Shen, W. Taheri, M. Wallenstein and M.N. Weintraub: Integrating legacy soil phosphorus into sustainable nutrient management strategies for future food, bioenergy and water security. Nutr. Cycl. Agroecosyst., 104, 393-412 (2016).

Sahrawat, K.L., S.P. Wani, G. Parthasaradhi and K.V.S. Murthy:
Diagnosis of secondary and micro-nutrient deficiencies and their management in rain-fed agro- ecosystems: case study from Indian semi-arid tropics. Comm. Soil Sci. Pl. Anal., 4, 346-360 (2010).

Shen, J., L. Yuan, J. Zhang, H. Li, Z. Bai, X. Chen, W. Zhang and F. Zhang: Phosphorus dynamics: from soil to plant. Plant Physiol., 156, 997-1005(2011).

Shi, L.L., S. Ming-Xing, L. Chang-Yin, W. Hai-Hou, Z. Xin-Wei, J. MeiJuan and W. Tong-Dong: Soil phosphorus dynamics, balance and critical $P$ values in long-term fertilization experiment in Taihu lake region, China. J. Integ. Agril., 14, 2446-2455 (2015).

Sibbesen, E.: An investigation of the anion-exchange resin method for soil phosphate extraction. Plant and Soil, 50, 305-321 (1978).

Singh, B., K.S. Khokhar and M. Kumar: Use of plastic mulching for quality vegetables. Inten. Agric., 42, 3-5 (2004).

Syers, K., A.E. Johnston and D. Curtin: Efficiency of soil and fertilizer phosphorus use: Reconciling changing concepts of soils phosphorus behaviour with agronomic information. FAO Ferti. PI. Nutri. Bull. 18: FAO, UN, Rome, Italy (2008).

Tarafdar, J.C., R.S. Yadav and S.C. Meena: Comparative efficiency of acid phosphatase originated from plant and fungal sources. $\mathrm{J}$. Plant Nutr. Soil Sci., 164, 745-751 (2001).

Wang, J., W.Z. Liu, H.F. Mu and T.H. Dang: Inorganic phosphorus fractions and phosphorus availability in a calcareous soil receiving 21-year superphosphate application. Pedosp., 20, 304-310 (2010).

Yadav, R.S., N.K. Jain, H.N. Meena, D. Bhaduri, P.K. Bhalodia, M. Bhadarka and D. Desai: Dynamics of soil phosphorus under different management practices for groundnut cultivation in calcareous Vertisols. J. Soil Water Conser., 16, 160-165(2017). 